\title{
UJI APLIKASI VAKSIN HYDROVAC UNTUK PENCEGAHAN PENYAKIT MERAH PADA IKAN MAS (Cyprinus carpio) DAN GURAME (Osphronemus gouramy) DI BALAI BENIH IKAN PANDAK KABUPATEN BANYUMAS
}

\author{
Indrawati*) dan Hambali Supriyadi**) \\ *) Dinas Peternakan dan Perikanan Kabupaten Banyumas \\ Jl. Ahmad Yani 30 A, Purwokerto \\ *) Pusat Riset Perikanan Budidaya \\ J. Ragunan 20, Pasar Minggu, Jakarta Selatan 12540
}

\begin{abstract}
ABSTRAK
Uji aplikasi vaksin ini bertujuan untuk mengetahui pengaruh pemberian vaksin hydrovac terhadap perkembangan kesehatan ikan mas dan gurami serta mendapatkan informasi tentang cara pengendalian, melalui tindakan pencegahan ikan air tawar yang terserang wabah penyakit Aeromonas hydrophila. Sebanyak 39 ekor ikan mas (Cyprinus carpio) dengan bobot rata-rata $1 \mathrm{~kg}$ dan panjang rata-rata $30 \mathrm{~cm}$ dan 108 ekor ikan gurami (Osphronemus gouramy L.) dengan bo bot rata-rata $250 \mathrm{~g}$ dan panjang rata-rata $10 \mathrm{~cm}$ yang berasal dari Balai Benih Ikan (BBI) Pandak Kabupaten Banyumas, digunakan sebagai ikan uji. Vaksin yang digunakan adalah "vaksin hydrovac" yang diproduksi oleh Laboratorium Patologi Ikan. Balai Riset Perikanan Budidaya Air Tawar, Bogor. Vaksin diaplikasikan dengan cara dicampur pelet dengan dosis 2--3 $\mathrm{mL}$ per kilogram bobot badan ikan yang diberikan selama 5--7 hari berturut-turut dan setelah satu bulan kemudian dilakukan vaksinasi ulangan (booster) terhadap ikan yang telah divaksin dengan cara yang sama. Hasil uji menunjukkan bahwa ikan baik ikan mas maupun gurame yang divaksin menunjukkan angka sintasan yang cukup tinggi apabila dibandingkan dengan ikan yang tidak divaksin. Mortalitas ikan uji yang tidak divaksin terjadi mulai minggu ke-5 dan ke-6.
\end{abstract}

KATAKUNCl: aplikasi, vaksin, hydrovac, penyakit merah, BBI Pandak, Banyumas

\section{PENDAHULUAN}

Ikan mas dan gurame merupakan komoditas ikan budidaya yang memiliki nilai ekonomis yang potensial.
Kedua jenis ikan tersebut banyak sekali dibudidayakan oleh pembudidaya ikan. Namun dalam usaha pembudidayaannya sering dihadapkan pada kendala wabah penyakit.

Penyakit bakterial merupakan salah satu masalah serius yang selalu dihadapi oleh pembudidaya ikan, karena penyakit tersebut selain dapat mengakibatkan kematian sekitar 50\%-100\%juga dapat menurunkan mutu daging dari ikan yang terinfeksi berupa borok atau luka sehingga tidak disukai oleh konsumen (Supriyadi et al., 2003).

Penyakit bakterial yang disebabkan oleh bakteri Aeromonas hydrophila menurut Roberts et al., 1992 dalam Angka (2001), dinamakan EUS (Ephyzootic Ulcerative Syndrome), sedangkan beberapa peneliti lain (Olga \& Aisiah, 2007) menamakannya M otileAeromonas Septicaemia (MAS). Penyakit ikan yang disebabkan oleh Aeromonas hydrophila juga sering disebut dengan beberapa nama yaitu "Haemorragic Septicaemia" atau "Infectious Abdominal Dropsy" (Stickney, 1979 dalam Angka, 2001).

Bakteri Aeromonas hydrophila dikenal sebagai patogen oportunis yang dapat menyebabkan ikan mengalami aeromoniasis yang dicirikan oleh adanya luka pada bagian tubuh dan siripnya, pendarahan pada luar tubuh dan organ dalam, kadang-kadang disertai oleh mata menonjol, lendir ikan banyak diproduksi tapi kemudian berkurang sehingga ikan kalau diraba terasa kesat dan ikan sering berada pada bagian permukaan perairan (Austin et al., 1996 dalam Sulistianingsih et al., 2004).

Tipe serangan penyakit ini meliputi per akut, yaitu tidak menunjukkan gejala apa-apa, tetapi langsung mati, sedangkan yang akut menimbulkan pendarahan di insang, anus, dan organ dalam, serta kadang-kadang juga didapatkan adanya cairan dan darah dirongga perut. Sedangkan pada serangan yang kronis ditunjukkan adanya pembengkakan yang kemudian berkembang menjadi tukak. Masa inkubasi penyakit ini antara 10--14 hari. 
Pencegahan dan pengendalian ikan harus dilakukan sedini mungkin, agar tidak terjadi kerugian ekonomi yang terlalu besar. Hingga kini, metode yang banyak digunakan untuk menanggulangi penyakit pada ikan budidaya adalah pengobatan dengan zat kimia atau antibiotik. Cara ini sangat berisiko karena dapat menimbulkan resistensi terhadap bakteri, memerlukan biaya yang cukup mahal, serta dapat mencemari lingkungan (Mariyono \& Sundana, 2002). Selain itu, dapat menimbulkan residu pada tubuh ikan yang kalau dikonsumsi dapat membahayakan kesehatan konsumen.

Usaha pengendalian penyakit yang efisien adalah dengan cara pencegahan. Salah satu cara yang saat ini sudah mulai banyak dilakukan adalah melalui peningkatan kekebalan tubuh yaitu antara lain dengan vaksinasi (Setyowati et al., 2004). Vaksinasi dapat dilakukan pada berbagai ukuran ikan dari benih sampai induk (Trianto et al., 1997 dalam Mulia, 2007). Cara tersebut sangat efektif dan efisien untuk mencegah penyakit MAS (Pasaribu et al., 1990; Kamiso et al., 1997 dalam Mulia, 2007). Namun demikian keberhasilan program vaksinasi tidak hanya ditentukan oleh keampuhan dari vaksin yang digunakan, tetapi juga sangat ditentukan oleh cara dan saat/waktu vaksin itu diberikan.

Dalam tulisan ini dikemukakan hasil hasil uji aplikasi penggunaan vaksin hydrovac untuk pencegahan penyakit bakterial pada ikan mas dan gurami. Adapun tujuan yang ingin dicapai dalam penelitian ini adalah untuk mengetahui pengaruh pemberian vaksin hydrovac terhadap perkembangan kesehatan ikan mas dan gurami serta mendapatkan informasi tentang cara pengendalian, melalui tindakan pencegahan ikan air tawar yang terserang wabah penyakit Aeromonas hydrophila.

Informasi tersebut diharapkan dapat bermanfaat bagi petani ikan dan para penyuluh lapangan.

\section{BAHAN DAN METODE}

Ikan yang digunakan adalah ikan mas (Cyprinus carpio) dan ikan gurami (Osphronemus gouramy L.) yang berasal dari Balai Benih Ikan (BBI) Pandak Kabupaten Banyumas. Jumlahnya mas uji adalah 39 ekor dengan bobot rata-rata ikan mas $1 \mathrm{~kg}$ dan panjang rata-rata $30 \mathrm{~cm}$. Sedang ikan gurami 108 ekor dengan bobot rata-rata ikan gurami 250 g dan panjang rata-rata $10 \mathrm{~cm}$.

Vaksin yang digunakan adalah "vaksin hydrovec" yang diproduksi oleh Laboratorium Patologi Ikan. Balai Riset Perikanan Budidaya Air Tawar, Bogor.

Vaksin diaplikasikan pada ikan mas (Cyprinus carpio) dan gurami (Osphronemus gouramy Lac.) dengan cara oral (pemberian vaksin yang dicampur pelet dengan dosis 2-$3 \mathrm{~mL}$ per kilogram bobot badan ikan yang divaksin selama 5--7 hari berturut-turut dan setelah satu bulan kemudian dilakukan vaksinasi ulangan (booster) terhadap ikan yang telah divaksin dengan cara yang sama. Pengamatan dilakukan terhadap gejala penyakit yang timbul serta kematian ikan uji, dengan interval pengamatan setiap seminggu sekali. Pengamatan juga dilakukan terhadap kualitas air selama uji aplikasi.

\section{HASIL DAN BAHASAN}

Kualitas air selama penelitian masih layak untuk kehidupan ikan mas dan gurami. Suhu air saat penelitian berkisar antara $24^{\circ} \mathrm{C}--30^{\circ} \mathrm{C}$ dan merupakan suhu yang optimum bagi kehidupan ikan mas dan gurami. pH air dalam penelitian berkisar antara 7--8 juga merupakan $\mathrm{pH}$ yang optimal bagi kehidupan ikan mas dan gurami.

Efektivitas vaksin hydrovac pada ikan mas dan gurami dapat dilihat dari respons tubuh dalam memproduksi antibodi. Pada minggu ke-5 terhadap ikan gurami kontrol (tanpa vaksin) mengalami kematian sebanyak 2 ekor dengan gejala penyakit pada sirip ekor, sirip punggung gripis dan pada tubuh ikan terdapat bercak merah. Sedangkan pada minggu ke-6 pada ikan mas kontrol (tanpa vaksin) mengalami morbiditas (tingkat kesakitan) sebanyak 2 ekor terdapat koreng pada tubuh ikan. Pada minggu ke-11 terdapat kematian 1 (satu) ekor pada ikan yang divaksin. Pada minggu ke-12 gurami kontrol mati 1 (satu) ekor walaupun kualitas air masih optimal. Pada minggu ke-13 gurami yang divaksin mati 1 (satu) ekor dan gurami kontrol (tanpa vaksin) 1 (satu) mati. Pada minggu ke-14 baik gurami maupun ikan mas semua dalam keadaan sehat dan memperlihatkan cukup aktif.

Ikan mas dan gurami yang tidak divaksin menunjukkan mortalitas tinggi apabila dibandingkan dengan ikan mas dan gurami yang divaksin. Sakai et al., 1995 dalam Indrawati (2006), menerangkan bahwa ikan yang divaksin menunjukkan mortalitas rendah. Hal ini menunjukkan bahwa vaksin berfungsi meningkatkan kekebalan tubuh spesifik (specific immunity) yang ditunjukkan dengan adanya antibodi (immoglobin spesifik) pada ikan yang divaksin.

Hasil penelitian Konzinska, 2000 dalam Mulia, 2007; menunjukkan bahwa vaksinasi dengan vaksin anti Aeromonas hydrophila dapat meningkatkan jumlah sel leukosit, limfosit, neutrofil, dan kemampuan fagositosis ikan karper dan beberapa peneliti juga melaporkan bahwa vaksinasi Aeromonas hydrophila dapat meningkatkan titer antibodi (Mulia, 2007). 
Efektivitas" vaksin Hydrovet" telah terbukti memiliki potensi untuk menginduksi respons kebal spesifik pada ikan mas maupun ikan gurami. Proses induksi kekebalan mulai dapat terdeteksi setelah 2--3 minggu dari saat pemberian vaksin terlihat pada pemberian vaksin pada minggu ke-14 ikan yang divaksin memperlihatkan aktivitas yang aktif dan sehat, begitu pula pada ikan gurami pada minggu ke-15 memperlihatkan aktivitas yang sehat sampai dengan 10 bulan ini dari pemberian vaksin hydrovec.

\section{KESIMPULAN DAN SARAN}

\section{Kesimpulan}

1. Pemakaian vaksin hydrovac menguntungkan karena mampu menimbulkan daya tahan tubuh pada ikan uji baik ikan mas maupun ikan gurame.

2. Ikan mas dan ikan gurami yang diberi vaksin hydrovec memperlihatkan aktifitas yang sehat.

\section{Saran}

Perlu digalakkan penggunaan vaksin hydrovac dengan metode yang tepat guna dan praktis di pembudidaya ikan.

\section{DAFTAR ACUAN}

Angka, S.L. 2001. Studi Karakterissasi dan Patogen Aeromonas hydrophila pada Ikan Lele Dumbo (Clarias gariepinus). Makalah Falsafah Sains. Program Pasca Sarjana (S3) Institut Pertanian Bogor. hlm. 1- 10.

Indrawati. 2006. Potensi Immunologik dan Histopatologik Probiotik Strain A3-51. Terhadap Ikan Nila Gift (Oreochromis sp.). Tesis Program Pasca Sarjana Universitas Jenderal Soedirman Purwokerto. $98 \mathrm{hlm}$.
Mariyono \& Sundana, A. 2002. Teknik Pencegahan dan Pengobatan Penyakit Bercak Merah pada Ikan Air Tawar yang disebabkan oleh Bakteri Aeromonas hydrophila. Buletin teknik Pertanian. 7(1): 1-40.

Mulia, D.S. 2007. Penggunaan Vaksin Debris Sel Aeromonas hydrophila Interval Waktu Booster Berbeda terhadap Respons Imun Lele Dumbo (Clarias gariepinus Burchell). Jurnal IImu-IImu Perairan, Sains Akuatik. Fakultas Perikanan dan IImu Kelautan Universitas Muhammadiyah Purwokerto. hlm 86- 95.

Olga \& Aisiah, S. 2007. Vaksin Protein produk Ekstraseluler Aeromonas hydrophila Untuk Meningkatkan tanggap Kebal Patin (Pangasius hypophthalamus) Terhadap Motile Aeromonas Septicemia (MAS)., Sains Akuatik. Fakultas Perikanan dan IImu Kelautan Universitas Muhammadiyah Purwokerto. Jurnal IImu-IImu Perairan. hIm 105- 110.

Setyowati, E.A., Dana, D., \& Pasaribu, F.H. 2004. Potensi Spirulina platensis Sebagai Imunostimulan Pada Ikan Gurami (Osphronemus gouramy Lac). Prosiding Pengendalian Penyakit Ikan dan Udang Berbasis imunisasi dan Biosecurity. Seminar Nasional Penyakit Ikan dan Udang IV. Purwokerto. hlm 157- 167.

Sulistyaningsih, A., Sukanto, \& Simanjuntak, B.I.S. 2004. Patogenitas Aeromonas pada kultur ikan gurami (Osphronemus gouramy Lac) yang diberi bakteri asam laktat TE2 dengan kepadatan berbeda. Prosiding Pengendalian Penyakit Ikan dan Udang Berbasisimunisasi dan Biosecurity. Seminar Nasional Penyakit Ikan dan Udang IV. Purwokerto. hlm 161- 167.

Supriyadi, H., Taufik, P., \& Taukhid. 2003. Karakterisasi patogen, inang spesifik dan sebaran mycobacteriosis. Jurnal Penelitian Perikanan Indonesia. 9(2). 